\section{JURNAL ABDIMAS

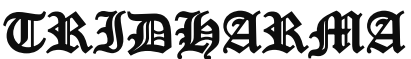

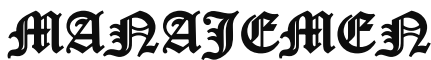

P-ISSN 2615-6849, E-ISSN 2622-3686

Jurnal ABDIMAS Vol. 1,No.1, Agustus 2019, Hal (66-76)

@Prodi Manajemen Fakultas Ekonomi Universitas Pamulang

Email: abdimasjurnal.unpam@gmail.com Telp: (021) 741-2566

\title{
DAMPAK BURUK PEMAKAIAN MEDIA SOSIAL TERHADAP SEMANGAT DAN CAPAIAN BELAJAR SISWA SMP ARRAISIYAH PAMULANG"
}

\author{
Nurwita, Fahmi Susanti, Dewi Nari Ratih Permada, Bulan Oktrima, Laila irawati \\ Dosen Ekonomi Fakultas Ekonomi Universitas Pamulang \\ Email Nurwitasalma@gmail.com, dosen02024@unpam.ac.id, \\ dewi.permada@gmail.com, dosen00790@unpam.ac.id, dosen02205@unpam.ac.id
}

\begin{abstract}
ABSTRAK
Pengabdian ini berjudul Dampak Buruk Pemakaian Media Sosial Terhadap Semangat dan Capaian Belajar Siswa SMP Arraisiyah Pamulang

Tujuan dilakasanakan pengabdian ini adalah untukmembantu siswa dan siswi dalam memahami literasi internet dan media sosial, dan memberikan wawasan siswa dan siswa tentang dampak buruk yang terjadi dari ketergantungan media sosial serta bagaimana Implementasi yang baik dengan pemakaian media sosial dengan bijaksana untuk meningkatkan semangat dan capaian belajar siswa

Metode pelaksanaan pengabdian ini adalah dengan mengadakan kunjungan kepada siswa dan siswi di SMPArraisiyah Pamulang dan memberikan pelatihan dan penyuluhan di lokasi tersebut.Persiapan yang dilakukan adalah segala hal yang terkait dengan materi, bahan dan alat sesuai dengan tema secara baik dan benar. Hasil persiapan tersebut dimaksudkan agar materi tersampaikan dengan dan mudah dimengerti serta dipahami oleh para siswa siswi SMP Arraisiyah Pamulangdan serta kami tidak lupa akan selalu memantau hasil dari pasca PKM ini apakah berhasil diterapkan sehingga mendapatkan hasil yang diharapkan dari tujuan PKM ini.

Kesimpulan dari pengabdian ini adalahMedia sosial di gemari oleh siswasiswi SMP Arraisiyah Pamulangdalam memperoleh informasi, Namun tidak sedikit para kalangan siswa-siswi melakukan penyalahgunaan media sosial mereka tidak sesuai aturan waktu sehingga menganggu waktu belajar dan menurunkan semangat dan capaian belajar.Denganadanya pengabdian kepada masyarakat ini dalam rangka pencegahan dampak buruk pemakaian media sosial terhadap semangat dan capaian belajar siswa. Dengan adanya materi ini siswa SMP ARRAISIYAH PAMULANG diharapkan dapat bertambah wawasan intelektual dalam pembentukan karakter yang baik dan bijaksana terhadap pemakaian media sosial sehingga dapat di manfaatkan untuk meningkatkan semangat dan capaian belajar siswa di sekolah menjadi lebih tinggi.
\end{abstract}

Kata Kunci: Dampak Buruk Pemakaian Media Sosial, Semangat dan Capaian Belajar Mahasis 


\section{JURNAL ABDIMAS

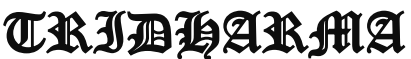

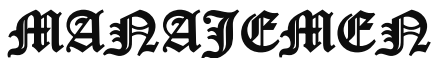

\section{ABSTRACT}

This dedication is entitled the Bad Impact of Social Media Use on the Spirit and Learning Achievements of Arraisiyah Pamulang Middle School Students

The purpose of this service is to assist students in understanding internet literacy and social media, and provide students and students insights about the adverse effects of social media dependency and how to implement good social wisdom wisely to increase enthusiasm and learning outcomes student The method of implementing this service is to conduct visits to students at Arraisiyah Pamulang Middle School and provide training and counseling at the location. The preparations made are all matters related to materials, materials and tools in accordance with the theme properly and correctly. The results of the preparation are intended so that the material is delivered with and easily understood and understood by Arraisiyah Pamulang Middle School students and we will not forget to always monitor the results of the post-PKM whether it is successfully implemented so as to obtain the expected results from the objectives of this PKM.

The conclusion of this dedication is that social media is favored by Arraisiyah Pamulang Middle School students in obtaining information, but not a few among students misuse their social media not according to the time rules so that disrupt learning time and reduce enthusiasm and learning achievements. With this community service in order to prevent the adverse effects of the use of social media on the enthusiasm and learning achievements of students. With this material, the students of SMP ARRAISIYAH PAMULANG are expected to gain intellectual insight in forming good and wise character towards the use of social media so that it can be utilized to increase the enthusiasm and learning achievements of students at school becoming higher.

\section{Keywords: Bad Impact of Social Media Use, Spirit, Learning Achievements}




\section{JURNAL ABDIMAS

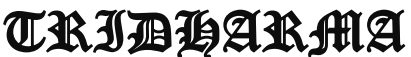

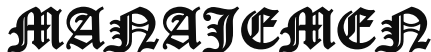

\section{PENDAHULUAN}

Perkembangan teknologi

informasi di era millenial ini semakin maju dan canggih dalam berbagai aspek kehidupan. Sehingga informasi dapat diakses kapan saja,dimana saja dan oleh siapa saja. Pada generasi millennial lebih suka mendapatkan informasi lewat internet dengan menggunakan ponselnya sehingga seperti diwajibkan untuk memiliki media sosial yang masa kini.Internet adalah salah satu sarana jaringan komputer yang paling tercepat dari teknologi- teknologi lainnya yang di dalam nya ada yang dinamakan Media Sosial. Apa yang dimaksud dengan Media sosial yaitu suatu media komunikasi berbasis online yang dimanfaatkan untuk pergaulan sosial yang para penggunanya dapat berkomunikasi, berinteraksi, berbagi teks,gambar, audio dan video satu sama lainnya. Contoh dari media sosial adalah Facebook, Twitter,You Tube, Whatsapp, Blogger, Instagram dll.

Perkembangan yang semakin maju ini akan memberikan dampak yang baik dan buruk di kehidupan khususnya di kalangan pelajar sosial media menjadi trend bahkan sampai menjadi candu yang tiada hari tanpa menggunakan media sosial tersebut. Pemakaian yang terus dan menerus setiap hari dapat mengurangi semangat dan capaian belajar siswa. Waktu yang seharusnya digunakan untuk belajar, malah digunakan untuk bermain di dunia maya ini secara langsung hal ini akan mengakibatkan penurunan prestasi yang dimiliki remaja tersebut (Arifin, 2009:9). Menurut Depedency Theory adalah kemudahan yang diberikan teknologi informasi dan komunikasi membuat para pemakainya memiliki ketergantungan.
Sehingga dominan terhadap dampak buruk jika tidak dilakukan upaya pencegahan dalam penggunaan sosial media secara bijak semenjak dini dapat menurunkan atau menghilangkan semangat dan capaian belajar siswa .

Oleh karena itu dengan pengabdian kepada masyarakat ini akan mengadakan program penyuluhan dini dalam rangka pencegahan dampak buruk pemakaian media sosial terhadap semangat dan capaian belajar siswa. Dengan adanya materi ini siswa SMP ARRAISIYAH PAMULANG diharapkan dapat bertambah wawasan intelektual dalam pembentukan karakter yang baik dan bijaksana terhadap pemakaian media sosial sehingga dapat di manfaatkan untuk meningkatkan semangat dan capaian belajar siswa di sekolah menjadi lebih tinggi

\section{RUMUSAN MASALAH}

Dengan memperhatikan latar belakang yang telah dipaparkan diatas kami akan mengadakan pengabdian kepada masyarakat tepatnya di lokasi SMP ARRAISIYAH PAMULANG membahas tentang penyuluhan dini dalam rangka pencegahan dampak buruk pemakaian media sosial terhadap semangat dan capaian belajar siswa .

Membekali para siswa dan siswi dengan penyuluhan materi penyuluhan dampak buruk media sosial terhadap semangat dan capaian belajar siswa di sekolah. 


\section{JURNAL ABDIMAS

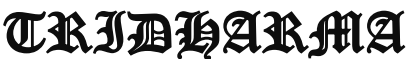

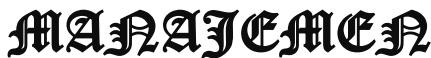

P-ISSN 2615-6849, E-ISSN 2622-3686

Jurnal ABDIMAS Vol. 1,No.1, Agustus 2019, Hal (66-76)

@Prodi Manajemen Fakultas Ekonomi Universitas Pamulang

Email: abdimasjurnal.unpam@gmail.com Telp: (021) 741-2566

\section{TUJUAN PELAKSANAAN}

1. Membantu siswa dan siswi dalam memahami literasi internet dan media sosial

2. Memberikan wawasan siswa dan siswa tentang dampak buruk yang terjadi dari ketergantungan media sosial

3. Memberikan Implementasi yang baik dengan pemakaian media sosial dengan bijaksana untuk meningkatkan semangat dan capaian belajar siswa

\section{TINJAUAN PUSTAKA}

Media sosial adalah suatu media yang dimanfaatkan sebagai sarana pergaulan sosial secara online di Internet.Internet (Interconnected Networking) sendiri ini diartikan adalah rangkaian komputer yang terhubung di dalam beberapa rangkaian jaringan.

Media sosial menurut para ahli di artikan sebagai berikut :

1. Media sosial adalah platform internet yang memungkinkan bagi individu berbagi secara segera dan berkomunikasi secara terus menerus dengan komunitasnya(Joyce Kasman Valenza ; 2014).

2. Media sosial adalah media Internet yang memungkinkan pengguna berkesempatan untuk berinteraksi dan mempresentasikan diri, baik secara seketika ataupun tertunda, dengan khalayak luas maupun tidak yang mendorong nilai dari user-generated content dan persepsi interaksi dengan orang lain(Caleb $\mathrm{T}$. Carr dan Rebecca A. Hayes ; 2015)

3. Media sosial adalah media yang digunakan oleh konsumen berbagi teks, gambar, suara, dan video informasi baik dengan orang lain maupun perusahaan dan vice versa(Philip Kotler dan Kevin Lane Keller ; 2016) .

Macam-macam media sosial adalah sebagai berikut:

\section{Facebook}

Media sosial buatan Mark Zuckerberg ini memang menduduki peringkat pertama media sosial yang paling banyak di gunakan di dunia.Saat ini Facebook merupakan media sosial paling populer di dunia. Sejak diluncurkan pada tahun 2004 silam Facebook sudah dilengkapi berbagai fitur canggih yang memanjakan para penggunanya, mulai dari yang awam soal internet sampai yang sudah ahli sekalipun tidak akan mengalami kesulitan menggunakan Facebook sebagai sarana berbagi informasi di dunia maya.

\section{Twitter}

Pada peringkat kedua media sosial yang paling populer di dunia adalah Twitter.Media sosial yang mirip dengan microblog ini tercatat sebagai media sosial yang paling aktif penggunanya.Sejak 


\section{JURNAL ABDIMAS

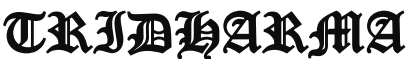

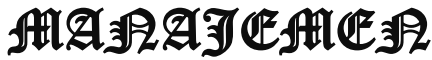

P-ISSN 2615-6849, E-ISSN 2622-3686

Jurnal ABDIMAS Vol. 1,No.1, Agustus 2019, Hal (66-76)

@Prodi Manajemen Fakultas Ekonomi Universitas Pamulang

Email: abdimasjurnal.unpam@gmail.com Telp: (021) 741-2566 diluncurkan tahun 2006 Twitter tumbuh dengan pesat dan saat ini sudah mencapai 284 juta pengguna. Bagi yang suka membagikan status yang singkat jelas dan padat . Hampir seluruh pengguna internet menggunakan Twitter, diantaranya selebritis, politikus, dan juga relawan untuk kepentingan masing masing.

\section{You Tube}

Sebuah situs web berbagi video yang dibuat oleh tiga mantan karyawan PayPal pada Februari 2005. Situs ini memungkinkan pengguna mengunggah, menonton, dan berbagi video.Pengguna tak terdaftar dapat menonton video, sementara pengguna terdaftar dapat mengunggah video dalam jumlah tak terbatas.

\section{Whatsapp}

Merupakan aplikasi pesan lintas platform online yang memungkinkan kita bertukar pesan tanpa biaya SMS, karena WhatsApp menggunakan paket data internet yang sama untuk email, browsing web, dan lainlain. Aplikasi WhatsApp menggunakan koneksi internet 3G, 4G atau WiFi untuk komunikasi data. Dengan menggunakan WhatsApp, kita dapat melakukan obrolan online, berbagi file, bertukar foto dan lain-lain

\section{Blogger}

Sebuah layanan publikasi blog yang dibuat oleh Pyra Labs dan diakuisisi oleh Google pada tahun 2003.Secara umum, blog yang dihost oleh Google berada di bawah subdomain blogspot.com.Blogger menawarkan dukungan blog banyak pengarang, yang memungkinkan pengguSna membuat sebuah blog untuk kelompok (group blog).

Blogger menawarkan fitur pengubahan template, yang mengizinkan pengguna mengubah desain template blog sesuai keinginan mereka. Bagi pengguna yang memiliki kemampuan pemrograman atau pemahaman kode CSS, fitur ini sangat berguna karena memungkinkan mereka merancang desain blog miliknya sendiri, antara lain dengan menambahkan sejumlah menu, dan kolom.

\section{Instagram}

Instagram merupakan media sosial tempat berbagi foto atau video yang paling populer saat ini. Pada awalnya Instagram hanya tersedia di aplikasi IOS (iphone / ipad), tapi saat ini sudah tersedia untuk berbagai OS yang lain seperti android, symbian, windows phone, dll.

\section{Fungsi dan tujuan media sosial sebagai berikut:}

\section{Media Komunikasi}

Media sosial sangat bermanfaat utuk Komunikasi dan interaksi dengan indivindu atau lebih, baik secara langsung atau tidak langsung. Misalnya dulu untuk 


\section{JURNAL ABDIMAS

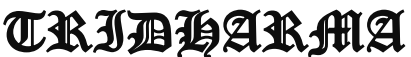

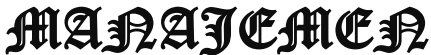

P-ISSN 2615-6849, E-ISSN 2622-3686

Jurnal ABDIMAS Vol. 1,No.1, Agustus 2019, Hal (66-76)

@Prodi Manajemen Fakultas Ekonomi Universitas Pamulang

Email: abdimasjurnal.unpam@ gmail.com Telp: (021) 741-2566 berkomunikasi dengan seseorang yang sangat jauh kita menggunakan - surat dan lama berbulan menunggu balasan daei surat tersebut dan sekarang Komunikasi tersebut bisa kita lakukan hanya dengan ponsel dan isi pulsa kuota., dengan Hanya menggunakan Koneksi internet kita sudah bisa melakukan komunikasi Seperti Facebook, Twitter, Instagram dll. Sudah semakin berkurang orang menggunakan Pulsa untuk berkomunikasi dan beralih menggunakan Paket Internet. Dari segi benefit, komunikasi dengan internet lebih menguntungkan, lebih cepat dan irit biaya.

\section{Media tempat curahan hati}

Curahan hati merupakan suatu cara yang dilakukan oleh seseorang untuk mengungkapkan perasaan. Didalam diri manusia ada berbagai macam persaan seperti sedih, bahagia, marah dll.orang menggunakan Media sosial sebagai ajang curahan hati. Ada 3 jenis cara yang bisa dilakukan menggunakan Tulisan, Foto dan Video.

\section{Mencari Informasi}

Kalau dulu biasanya jika kita ingin mencari informasi harus melalui koran, buku, majalah, televisi. sekarang ini sudah dimudahkan melalui media social.. Nah, Ada berbagai jenis Informasi yang ada seperti Infomasi ; Kesehatan, Pendidikan, Berita, Teknologi dll. Kelebihan dari Informasi Media Sosial adalah informasi yang tersebar begitu cepat, bisa hitungan jam, menit bahkan detik, informasi sudah bisa disebar luaskan.

\section{Media Belajar}

Media sosial untuk sarana belajar, kita sudah tidak perlu repot-repot untuk membeli buku di zaman canggih ini.Karena Pelajaran apapun yang kita ingin pelajari sudah ada di media sosial. Baik itu Pelajaran ; Komputer, Ekonomi, Politik, Sosial, Budaya, Hukum dll, bisa kita dapatkan dari Intenet.

\section{Menambah Teman}

Media sosial untuk menambah teman kita harus bertatap muka dan bertemu secara langsung telebih dahulu dan memperkenalkan diri, sekarang tidak harus melakukan hal tersebut kita bisa manambah teman melalui Facebook, Instagram dll.Sehingga, kita bisa mengenal banyak orang dari seluruh dunia.

\section{Media Untuk Berbagi}

Media Sosial juga dimanfaatkan oleh seseorang untuk berbagi informasi, tulisan, foto dan video dengan sangat mudah. Misalkan facebook, biasanya untuk berbagi dengan teman, kita menandai mereka satu persatu atau membagikan ke beranda masing-masing. 


\section{JURNAL ABDIMAS

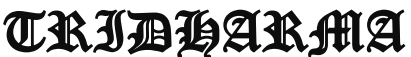

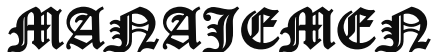

P-ISSN 2615-6849, E-ISSN 2622-3686

Jurnal ABDIMAS Vol. 1,No.1, Agustus 2019, Hal (66-76)

@ Prodi Manajemen Fakultas Ekonomi Universitas Pamulang

Email: abdimasjurnal.unpam@ gmail.com Telp: (021) 741-2566

\section{Mencari Amal}

Media Sosial bisa gunakan untuk mencari amal kebaikan untuk akhirat. Ada Berbagai Macam Cara yang bisa kita lakukan untuk mencari amal seperti ; dengan cara membuat kata-kata Motivasi, Insppirasi, Tausiyah, Video Tausiyah dan Poster Dakwah. Contohnya Halaman Inovasi Dakwah dan grup Islam Agama ku adalah Halaman/grup yang bertujuan untuk menyampaikan Ajaran Islam.

\section{Membangun Komunitas}

Manfaat yang sangat menarikdari media sosial adalah kita bisa membangun komunitas pada media sosial.Biasanya, untuk membangun komunitas orangorang memanfaatkan Facebook, Instagram. Komunitas yang dibangun bisa Dalam Bentuk Halaman(FansPage) atau Grup (group). Komunitas yang kita bangun bisa mencapai jumlah anggota yang sangat banyak ; bisa ratusan, ribuan dan bahkan jutaan. Ada berbagai komunitas yang bisa kita bangun seperti : Komunitas Pecinta Alam, Keagamaan, Blogger, Hacker dll.

\section{Mencari Uang}

Media Sosial Bisa dimanfaatkan seseorang untuk mencari uang dengan cara menyediakan jasa. Baik itu jasa pembuatan Website, Desain, Video Editing dll.Ada juga orang memanfaatkan Blog untuk mencari uang, yaitu dengan memanfaatkan fasilitas Google Adsense untuk pemasangan iklan.

\section{Media Promosi}

Kehebatan media sosial adalah tempat untuk Mempromosikan produk dan jasa yang bergerak didunia nyata dengan cara bermain didunia maya.trik promosi dengan media sosial sangatlah berpengaruh terhadap kemajuan dari produk dan jasa.di samping lebih hemat dibandingkan memasang iklan di tv atau radio yang nilainya jutaan rupiah hingga ratusan juta rupiah.

\section{Media Penyimpanan}

Manfaat pentingnya media sosial adalah tempat penyimpanan foto dan video. Apapun yang telah dipublikasikan akan tersimpan di internet. Andaikan foto dan video telah terhapus pada memori, kita masih bisa mendapatkannya kembali dari media sosial denganpassword dan username yang pernah kita upload dan tidak memakan biaya tinggi hanya dengan kuota internet dibandingkan membeli flashdisk dengan harga yang mahal.

Di bawah ini adalah dampak baik dan buruk dalam menggunakan media sosial:

Dampak baik :

- Menjaga silaturahim dengan keluarga ataupun saudara yang 


\section{JURNAL ABDIMAS

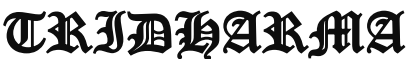

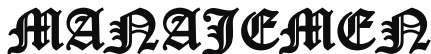

P-ISSN 2615-6849, E-ISSN 2622-3686

Jurnal ABDIMAS Vol. 1,No.1, Agustus 2019, Hal (66-76)

@Prodi Manajemen Fakultas Ekonomi Universitas Pamulang

Email: abdimasjurnal.unpam@ gmail.com Telp: (021) 741-2566 jauh dan sudah lama tidak bertemu, sekalipun yang belum dikenal di seluruh dunia.

- Sebagai sumber belajar dan mengajar media sosial memiliki dampak yang sangat besar sekali. Kita dapat browsing dan belajar ilm pengetahuan yang baru disana. Karena internet banyak topik dan sumber ilmu terbaru. Dengan mencari topik diinternet anda selangkah lebih maju saat memulai pembelajaran didalam kelas.

- Media penyebaran informasi. Hanya dalam tempo beberapa menit setelah kejadian, kita telah bisa menikmati informasi tersebut..

- Media sosial sebagai media promosi dalam berbisnis. Hal dini memungkinkan para pengusaha kecil dapat mempromosikan produknya tanpa mengeluarkan biaya yang besar hanya dengan kuota internet.

Dampak buruk :

\section{Tidak adanya Waktu Belajar} Siswa

- Sulit bersosialisasi dengan orang-orang sekitar. Disebabkan karena mereka malas belajar berkomunikasi secara nyata. Orang yang aktif dalam dunia maya yaitu media sosial, jika bertemu lansung nyatanya adalah orang yang pendiam dan tidak banyak bergaul.
- Tidak adanya Waktu Belajar SiswaHal ini sudah jelas, karena dengan mengakses internet dan membuka situs jejaring sosial siswa akan lupa waktu, sehingga yang dikerjakannya hanyalah itu-itu saja yang tidak ada waktu belajar.

- Membuka internet untuk situs jejaring sosial jelas berpengaruh terhadap kondisi keuangan siswa (terlebih kalau akses dari warnet). Tidak jarang siswa menggunakan uang SPP mereka untuk pergi ke warnet ataupun membeli kuota internet sekedar untuk membuka situs jejaring sosial saja. Ini dapat dikategorikan sebagai pemborosan, karena menggunakan uang secara tidak produktif

- Media sosial membuat seseorang memiliki sifat individualisme. Mereka menjadi tidak sadar dengan lingkungan mereka, karena mereka banyak menghabiskan waktu di internet.

- Penurunan kinerja, karyawan perusahaan, pelajar, mahasiswa yang bermain media sosial pada saat mengerjakan pekerjaannya akan mengurangi waktu kerja dan waktu belajar mereka.

- Kejahatan dalam dunia maya. Kejahatan ini dikenal dengan sebutan cyber crime. Kejahatan dunia sangat banyak macamnya seperti :hacking, cracking, spaming, dan lainnya. Yang berujung pada kematian dan penipuan. 


\section{JURNAL ABDIMAS

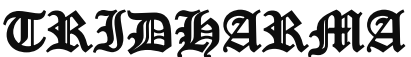

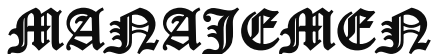

P-ISSN 2615-6849, E-ISSN 2622-3686

Jurnal ABDIMAS Vol. 1,No.1, Agustus 2019, Hal (66-76)

@ Prodi Manajemen Fakultas Ekonomi Universitas Pamulang

Email: abdimasjurnal.unpam@ gmail.com Telp: (021) 741-2566
- Pornografi. kemampuan informasi yang dimiliki internet, pornografi pun merajalela. Terkadang seseorang memposting foto yang seharusnya menjadi privasi sendiri di media sosial. Hal ini sangat berbahaya karena bisa jadi postingan tersebut digunakan oleh pihak yang tidak bertanggung jawab atau yang menyalahgunakan.

Dari paparan dampak situs Media sosial di atas, adapun langkah strategis yang dapat dilakukan untuk pengimplementasian gagasan yaitu sebagai berikut:

- Memberikan Pemahaman kepada Siswa Tentang Bahaya Situs Media Sosial

Langkah ini perlu dilakukan agar para siswa tahu bahaya dari penggunaan situs jejaring sosial, dan dapat menggunakannya secara lebih bijak.Selain itu langkah ini juga dapat menimbulkan rasa waspada kepada siswa sehingga dalam menggunakan situs jejaring sosial mereka lebih berhati-hati banyak menimbulkan kasus kejahatan Dan antiripasi bagi guru yang tidak memperbolehkan siswa membawa hp ke dalam kelas dan saat kegiatan belajar mengajar.

- Mengawasi Siswa dalam Berinternet atau Berjejaring Sosial

Pengawasan terhadap pergaulan siswa dalam jejaring sosial dunia maya sangat diperlukan, karena jika siswa tidak diawasi mereka akan dengan mudah mengakses situs jejaring sosial tersebut dan menggunakannya kea rah yang tidak baik. Pergaulan mereka akan mudah melawan perkataan orang tua, dan usaha kita untuk menyelamatkan anak untuk tidak menggunakan akses internet secara berlebihan akan sia-sia dan tidak mendapatkan hasil yang maksimal. Pergaulan anak yang bebas dan pengaruh dari teman-teman juga dapat memudahkan anak untuk mengakses situs jejaring sosial dengan mudah.Maka dari itu mereka perlu diawasi untuk tidak mengakses internet dengan bebas.

\section{METODE PELAKSANAAN}

Metode kegiatan yang digunakan adalah kita mengadakan kunjungan kepada siswa dan siswi di SMP ARRAISIYAH PAMULANG dan memberikan pelatihan dan penyuluhan di lokasi tersebut

Persiapan yang dilakukan adalah segala hal yang terkait dengan materi, bahan dan alat sesuai dengan tema secara baik dan benar. Hasil persiapan tersebut dimaksudkan agar materi tersampaikan dengan dan mudah dimengerti serta dipahami oleh para siswa siswi SMP ARRAISIYAH PAMULANG dan serta kami tidak lupa akan selalu memantau hasil dari pasca PKM ini apakah 


\section{JURNAL ABDIMAS

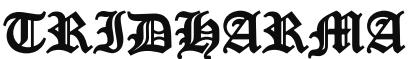

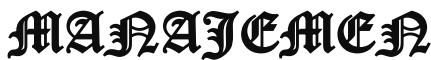

P-ISSN 2615-6849, E-ISSN 2622-3686

Jurnal ABDIMAS Vol. 1,No.1, Agustus 2019, Hal (66-76)

@Prodi Manajemen Fakultas Ekonomi Universitas Pamulang

Email: abdimasjurnal.unpam@ gmail.com Telp: (021) 741-2566 berhasil diterapkan sehingga mendapatkan hasil yang diharapkan dari tujuan PKM ini.

\section{HASIL DAN PEMBAHASAN}

Pelaksanaan kegiatan Pengabdian Kepada Masyarakat oleh Lembaga Penelitian dan Pengabdian Masyarakat (LPPM) Universitas Pamulang yang dilakukan oleh dosen-dosen program studi Manajemen telah berjalan dengan lancar dan mendapat sambutan hangat dari tempat pelaksanaan kegiatan ini di SMP ARRAISIYAH PAMULANG

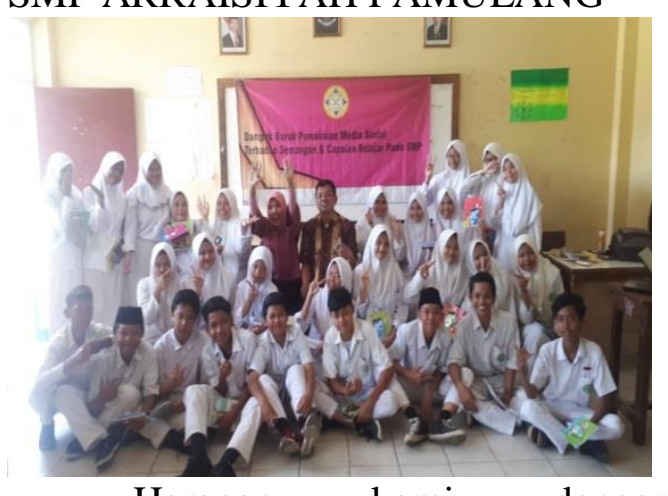

Harapan kami dengan
pengabdian ini dapat membuka wawasan dari siswa siswi kelas 12 yang akan menghadapi dunia perguruan tinggi dan dunia kerja. Materi yang kami berikan yaitu pembelajaran tentang penggunaan media sosial secara bijaksana, sekaligus bahan kajian dan masukan bagi para siswa/siswi tersebut untuk dapat mengimplementasikannya dalam kehidupan sehari-hari, sehingga dapat membantu dan meningkatkan tingkat keilmuan dan keperibadian yang yang akan sangat bermanfaat dalam kehidupan mereka pada masa yang akan datang.

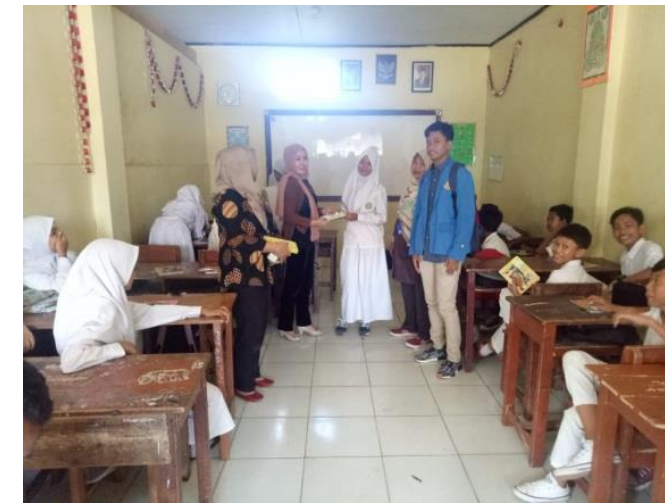

Dalam laporan kegiatan ini mungkin banyak kekurangan yang ada, untuk itu kami berharap masukan dan kritikan dalam rangka perbaikan untuk kegiatan-kegiatan pengabdian masyarakat di masa yang akan datang. Semoga kegiatan pengabdian masyarakat ini dapat bermanfaat bagi masyarakat sekitar lingkungan Universitas Pamulang. Dengan adanya materi ini tentang mengenal lebih jauh literasi digital dan dampak negatif penggunaan media sosial jika tidak digunakan dengan bijaksana. Sehingga siswa SMA Negeri 6 Tangerang Selatan menjadi bertambah wawasan intelektualnya serta membuka cara fikir mereka tentang penggunan litarasi digital yang bijaksana sebaga siswa pelajar.

\section{KESIMPULAN DAN SARAN}

Kesimpulan

Media sosial di gemari oleh siswasiswi SMP ARRAISIYAH PAMULANG dalam memperoleh informasi, Namun tidak sedikit para kalangan siswa-siswi melakukan penyalahgunaan media sosial mereka tidak sesuai aturan waktu sehingga menganggu waktu belajar dan menurunkan semangat dan capaian belajar. 


\section{JURNAL ABDIMAS

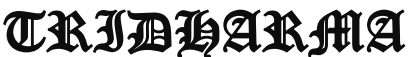

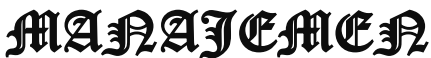

P-ISSN 2615-6849, E-ISSN 2622-3686

Jurnal ABDIMAS Vol. 1,No.1, Agustus 2019, Hal (66-76)

$@$ Prodi Manajemen Fakultas Ekonomi Universitas Pamulang

Email: abdimasjurnal.unpam@ gmail.com Telp: (021) 741-2566
Saran

Denganadanya pengabdian kepada masyarakat ini dalam rangka pencegahan dampak buruk pemakaian media sosial terhadap semangat dan capaian belajar siswa. Dengan adanya materi ini siswa SMP ARRAISIYAH PAMULANG diharapkan dapat bertambah wawasan intelektual dalam pembentukan karakter yang baik dan bijaksana terhadap pemakaian media sosial sehingga dapat di manfaatkan untuk meningkatkan semangat dan capaian belajar siswa di sekolah menjadi lebih tinggi.

\section{DAFTAR PUSTAKA}

Arikunto, Suharsimi. 2008. DasarDasar Evaluasi Pembelajaran. Jakarta: Bumi Aksara. 308 hlmn.

A.M. Sardiman, 2001. Interaksi dan Motivasi Belajar Mengajar. Jakarta: Raja GrafindoPersada. 224 hlmn.

Kartini Kartono, 2008, Pemimpin dan kepemimpinan. Jakarta: Raja Grafindo Persada

Pasaribu, V. L. D., Susanti, F., \& Hartuti, E. T. K. (2019). MEMOTIVASI SISWA DAN SISWI SMK LETRIS INDONESIA DI DALAM MENENTUKAN PILIHAN UNTUK MELANJUTKAN PENDIDIKAN ATAU BEKERJA SETELAH LULUS SEKOLAH. Jurnal Pengabdian Dharma Laksana, 1(2), 161-172. https://pakarkomunikasi.com/penger tian-media-sosial-menurut-para-ahli. diakses tanggal 5 februari 2019

https://sarungpreneur.com/inilahmacam-macam-sosial-media-yangpopuler-di-dunia/diakses tanggal 5 februari 2019

https://solusimedsos.blogspot.com/2 017/01/Manfaat-dan-TujuanMenggunakan-Media-Sosial-2017.html

Prijosaksono, Aribowo dan Sri Bawono.2005. The Power of Entrepreneurial Intelligence,Membangun Sikap dan Perilaku Entrepreneur Dalam Diri Anda.Elex Media Komputindo, Jakarta

Kartini Kartono, 2008, Pemimpin dan kepemimpinan. Jakarta: Raja Grafindo Persada 